PLANTS PEOPLE

POSSIBILITIES

\title{
The Raised Turf System of Planting Bog-Land
}

\section{Author(s): W. Dallimore}

Source: Bulletin of Miscellaneous Information (Royal Botanic Gardens, Kew), Vol. 1911, No. 5 (1911), pp. 226-228

Published by: Springer on behalf of Royal Botanic Gardens, Kew

Stable URL: http://www.jstor.org/stable/4118393

Accessed: 27-06-2016 02:37 UTC

Your use of the JSTOR archive indicates your acceptance of the Terms \& Conditions of Use, available at

http://about.jstor.org/terms

JSTOR is a not-for-profit service that helps scholars, researchers, and students discover, use, and build upon a wide range of content in a trusted digital archive. We use information technology and tools to increase productivity and facilitate new forms of scholarship. For more information about JSTOR, please contact support@jstor.org.

Royal Botanic Gardens, Kew, Springer are collaborating with JSTOR to digitize, preserve and extend access to Bulletin of Miscellaneous Information (Royal Botanic Gardens, Kew) 
peripherica, densissime constipata. Asci cylindracei, 100-120 $\times$ $7-8 \mu$, basi attenuati. Sporae filiformes, longitudine ascorum, hyalinae, multiseptatae.

Malay Peninsula. Johor: Mount Austin, on the inflorescence of Ichnanthus pallens, Munro. Ridley, 12,508.

In this species the ovary of the host is converted into a black sclerotium, which produces a single, stipitate, ascigerous stroma. Allied to Balansia Jungueri, P. Henn., but much smaller in every part.

Gibbera tinctoria, Massee.

Perithecia epiphylla, densissime aggregato-constipata, crustam atram superficiem foliorum obtegentem efficicientia, globosa, purpureo-atra, rugulosa, ostiolo papillulato donata, $0.5 \mathrm{~mm}$. diam., contextu minutissime parenchymatico sordide purpureo. Asci cylindraceo-clavati, apice crassiuscule tunicati, basi attenuatopedicellati, $80 \times 7-8 \mu$. Sporae oblique distichae, ellipsoideae, utrinque rotundato-truncatae, 1-septatae, dilutissime flavae, 11-12 $\times 5-6 \mu$.

Tropical Africa. Rhodesia: on leaves of Monotes glaber, Sprague. Allen, 734 .

This species was first detected by my colleague, Mr. T. A. Sprague, B.Sc., on phanerogamic material sent to Kew for determination. Differs from Gibbera Vaccinii, Fr., in the much smaller, and relatively narrower spores, and in the dingy purple colour of the tissue of the perithecium. When treated with a dilute solution of potassic hydrate a brilliant purple colouring matter is liberated.

\section{HYPHOMY CETES.}

Hainesia aurantiaca, Massee.

Acervuli subcutanei, sparsi, vix pulvinati, parvuli, 0.5-1 mm. diametro, saepe confluentes, laete aurantiaci, dein pallescentes. Sporulae ellipticae, utrinque latissime rotundatae, hyalinae, saepe curvulae, $10-12 \times 3-3.5 \mu$, in sterigmatibus e strato prolifero fusco exsurgentibus filiformes, hyalinae, solitariae, acrogenae.

Quennsland. On the pericarp of Endiandra insignis, Bailey.

Distinguished from its nearest ally, Hainesia rhoina, Ell. and Sacc., by its clear orange colour and somewhat larger sporules.

Explanation of Figures.

Figs. 1-7. - Balansia asperata.

Figs. 8-10. - Balansia sessilis.

Figs. 11-14.-Aecidium osyridocarpi.

Figs. 15-17.-Ustilago trichopterygis.

\section{XXVII.-THE RAISED TURF SYSTEM OF PLANTING BOG-LAND.}

(With Plates.)

W. Dallimore.

The successful planting of wet, boggy land is one of the most difficult problems the forester has to deal with, and when such conditions prevail at a high elevation and an unsatisfactory climate has also to be considered, the planter finds full scope for his abilities. 
In the past the great difficulty has been the proper draining and aerating of the ground at such a cost as would bring the work within the limits of practical commercial forestry, for, although in many cases proper draining would have been quite practicable, the cost was prohibitive. On the other hand, the opening of surface drains 15 to 20 feet apart, which could be done at a small cost, had little effect in districts where the rainfall was heavy, consequently the ground never became suitable for tree growth. A certain amount of success has attended ridging, especially where the ground has not been very wet to begin with, but this method of planting is not applicable to all circumstances.

For some years past a system of planting bog-land has obtained in Belgium which, though really an old system revived, has come to be known as the "Belgian system" or " raised turf system" of planting. This consists of opening drains 6 or 8 feet apart and 12 to 18 inches deep. The turves obtained during the process are laid face downwards at distances of 3 or 4 feet apart, the distance being regulated by the spacing of the trees. The turves are allowed to dry for several months, sometimes a year, during which time they become well aired and sweet. At planting time-April or May are considered the best months for the work-a circular hole is made in each turf. The soil removed is mixed with a handful or two of sharp sand and sometimes with a little basic slag, and placed around the roots of the young tree as it is being planted. Trees from two to three years old are found to be most satisfactory for the purpose.

About 1906 or 1907 this method of planting claimed the attention of Sir John Stirling Maxwell, Bart., one of the greatest enthusiasts in forestry matters in Scotland, who for 10 years or so had been experimenting with the planting of bog-land on his Invernessshire estate at Fersit and Corrour, at altitudes varying between 800 and 1400 feet. At the higher elevations and under the worst conditions his experiments had met with little success, and he was convinced that the usually adopted measures could end in nothing but failure. Seeing that the "Belgian system" had much in its favour he decided to give it a good trial and described the method of culture in the "Transactions of the Royal Scottish Arboricultural Society," vol. xx, pp. 1-7. After a trial of three years the results were circulated through the medium of the same publication in 1910, vol. xxiii, pp. 153-157. The results as published there give overwhelming evidence of the superiority of this method of culture over those already tried, while details of cost show that it is well within the bounds of practical forestry. A description of the experiments from notes made during a visit to the experimental area last June may also be found in the Kew Bulletin, 1910, pp. 242-243.

The kindness of Sir John Stirling Maxwell in presenting specimens of young trees grown under both old and new systems of culture, for the Forestry Museum at Kew, has been the means of obtaining the accompanying photographs. The following explanatory remarks about the plants figured have been furnished by Mr. D. Grant, forester to Sir John at Fersit :-

" No. 1. Sitka spruce raised in Pollok seed beds, and lined one year in Fersit nursery. Planted on turf (Belgian system) age

20080 
two year (in seed bed), one year (transplanted), in April, 1909. Two handsful of gravel used to each plant. No manure used.

"No. 2. Sitka spruce raised in Pollok seed beds, lined one year in Fersit nursery, and notched on natural surface, April, 1909.

"No. 3. Sitka spruce (German) two year, one year, planted straight out on turf, April, 1909, with two handsful of gravel to each plant. No manure used.

“ No. 4. Sitka spruce (German) two vear, one year, notched straight out on natural surface, April, 1909 .

"No.-5. Pinus montana var. uncinata, raised in Pollok seed beds, lined one year in Fersit nursery, planted on turf, age two vear, one year, April, 1910, two handsful of gravel used to each plant. No manure used.

"No. 6. Pinus montana var. uncinata, same as No. 5. Notched in natural surface, A pril, 1910."

The leading shoots of three plants of number one, representing last year's height growth, were $14,11 \frac{1}{2}$ and $11 \frac{1}{2}$ inches respectively, while last year shoots of number two measured 2, 2 and $2 \frac{1}{2}$ inches. The difterence in colour was also very marked, for, while the leaves of the first three were of a dark, healthy green, those of the second three were yellow and undersized. Numbers three and four exhibited similar differences, but the turf-grown plants had made less vigorous growth than those raised from seeds sown in Scotland. In the case of number five the shoots were strong, the buds healthy, and the foliage full sized, plants of number six being small, weak and yellowish, with undersized leaves. In each instance the root system of the turf-grown examples was greatly in excess of that of plants grown in the natural bog.

The great advantage gained by this mode of culture is in producing a mass of sweet, well drained soil, which will supply the needs of a young plant for a couple of years or so whilst the natural peat below is gradually drying and sweetening, processes which are made possible by the closeness of the drains. When the food material in a raised turf is exhausted the roots are able to penetrate into that which is below. Sitka spruce is very popular for this kind of planting, whilst oriental spruce, common spruce, white spruce and Pinus montana var. uncinata are also planted. Scots pine has been tried but has been discarded from the wetter land. The area under cultivation at Corrour and Fersit is of considerable extent, and as the land lies in a cold and bleak position the experiments which are being carried on there will be watched with great interest during the next few years, for if the present system of planting turns out to be as successful as it promises to be at the present time, a great deal of land may be covered with trees which in the past has been considered to be quite out of the question. Several years must, however, elapse, especially where high ground is concerned, before a definite opinion can be formed of the results of the venture. Sir John has kindly presented two large photographs illustrating this method of planting, which have been placed on exhibition in the Forestry Museum. 


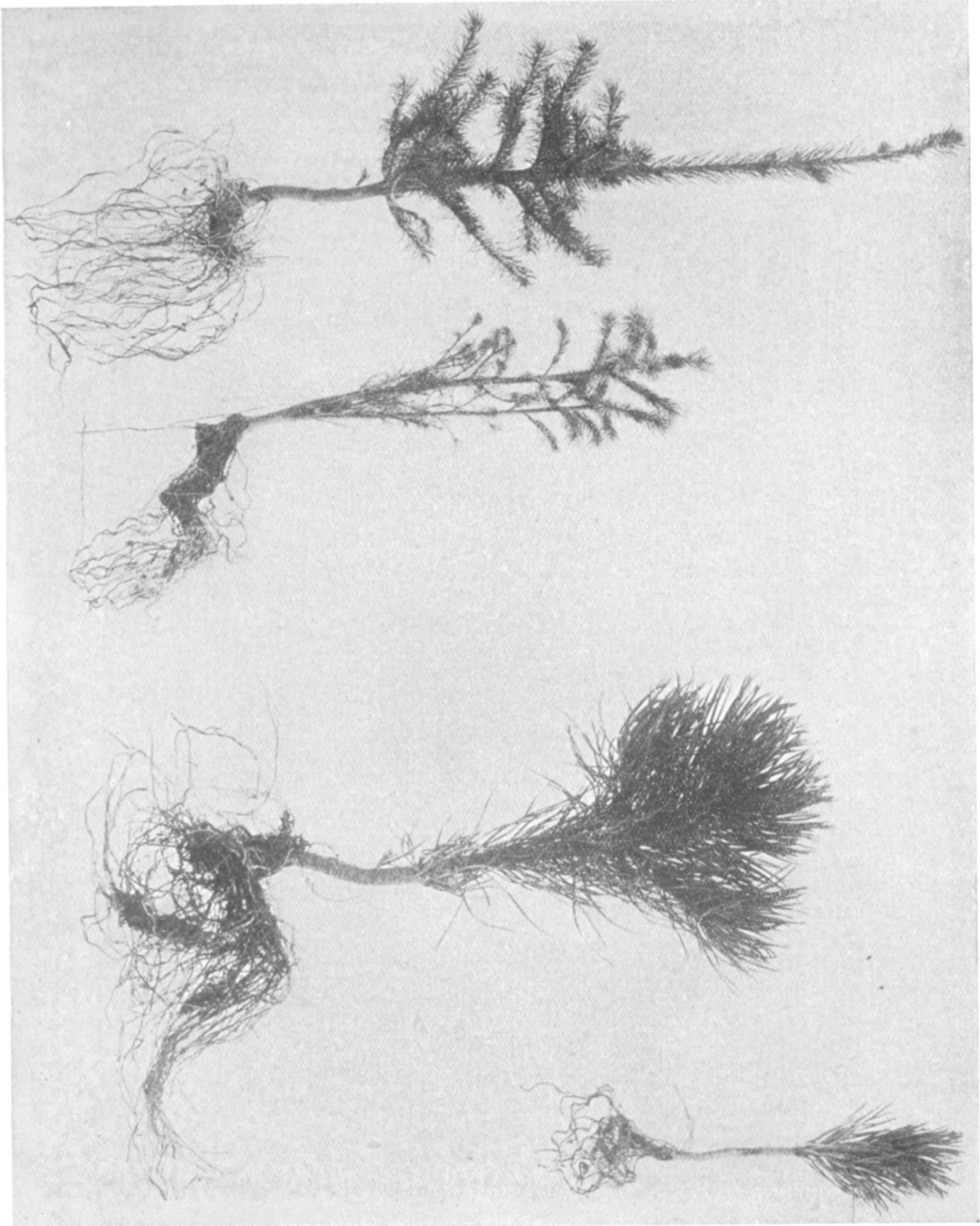


Kew Bulletin, 1911.

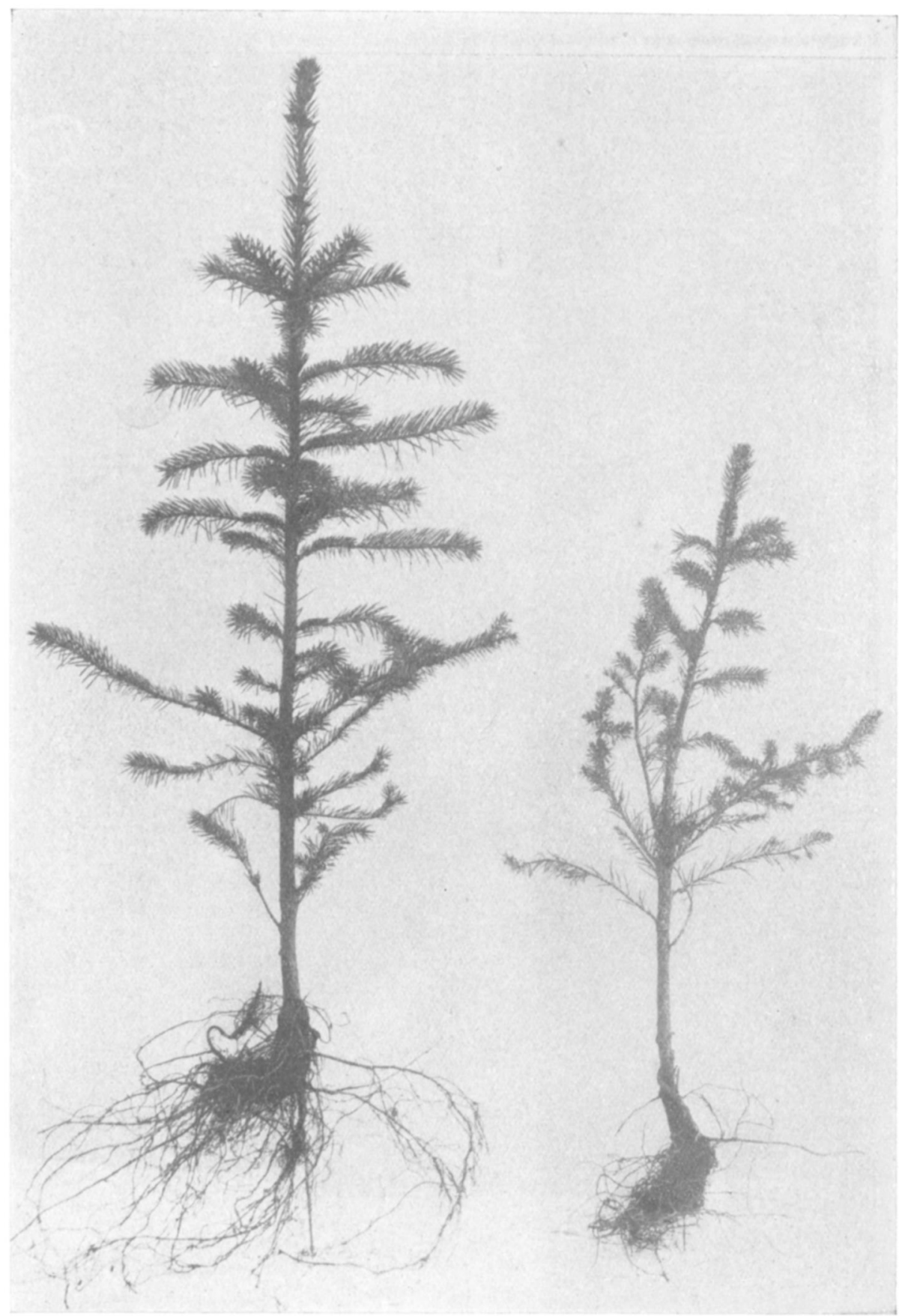

3.

4.

To face page 229.]

This content downloaded from 128.42.202.150 on Mon, 27 Jun 2016 02:37:01 UTC All use subject to http://about.jstor.org/terms 